\title{
Tissue distribution of retinoids in common dolphins Delphinus delphis
}

\author{
Victoria Tornero ${ }^{1, *}$, Asunción Borrell $^{1}$, Jaume Forcada $^{2}$, Álex Aguilar ${ }^{1}$ \\ ${ }^{1}$ Department of Animal Biology (Vertebrates), Faculty of Biology, University of Barcelona, Diagonal 645, 08071 Barcelona, Spain \\ ${ }^{2}$ Biological Sciences Division, NERC, British Antarctic Survey, High Cross, Madingley Road, Cambridge CB3 0ET, UK
}

\begin{abstract}
Exposure to organochlorines induces retinoid deficiency in mammals; hence, retinoids are potential biomarkers of the impact of these pollutants. Appropriate target tissues to monitor retinoids in cetaceans have not been properly identified because of a lack of information on the contribution of each tissue to total body retinoids. Therefore, we have addressed this issue by studying the contribution of the main body tissues to retinoids in 21 common dolphins obtained from incidental catches and in apparent good health and nutritive condition. Although concentrations in the liver were highest, those in blubber were also high and accounted for $43 \%$ of the total retinoid load of the compartments examined. As blubber can be obtained using non-invasive biopsy techniques, this tissue is proposed as a reliable indicator of retinoid status in cetaceans. However, blubber topographical variation in structure and composition requires standardization of sampling sites. Retinoid concentrations did not differ significantly between sexes or with body size for any of the tissues, but the lipid content of blubber strongly influenced these concentrations. Biopsies from healthy, freeranging individuals are preferred to samples from stranded animals. Further research on the influence of factors (age, sex, reproductive condition, diet) that potentially affect retinoid levels is required to implement the use of retinoids as biomarkers of pollutant exposure in cetaceans.
\end{abstract}

KEY WORDS: Retinoids · Common dolphin $\cdot$ Compartmentation $\cdot$ Blubber $\cdot$ Biomarker $\cdot$ Northwestern Spain Resale or republication not permitted without written consent of the publisher

\section{INTRODUCTION}

Linking the tissue concentration of a given contaminant with its effect on an organism is a major challenge in environmental toxicology. Biomarkers, defined as contaminant-induced variations in the cellular or biochemical components of a process, structure or function that can be assessed in a biological system (NRC 1989), are being developed and applied to establish such a relationship. Biomarkers are expected to provide an integrated measure of the response of an organism to exposure to a chemical or group of chemicals and, hence, a measure of toxicological risk (McCarthy \& Shugart 1990, Depledge \& Fossi 1994). Pollution by organochlorines is a source of concern for top predator cetaceans and pinnipeds (Reijnders \& Aguilar 2002). Substantial literature reports the monitoring of these compounds in this group (O'Shea \& Aguilar 2001). However, the application of biomarkers remains incipient.

In mammals, body levels of retinoids are disrupted by organochlorine compounds, particularly polychlorinated biphenyls (PCBs). Consequently, retinoids have been proposed as sensitive biomarkers (Peakall 1992, Murk et al. 1998) and several studies have addressed their potential application to marine mammals (Rolland et al. 2000, Simms \& Ross 2000, Borrell et al. 2002). Retinoids are a family of lipid-soluble substances that possess Vitamin A-like biological activity, including compounds such as retinol and retinol derivatives, retinal, retinyl palmitate and retinoic acid (Blomhoff et al. 1992). In mammals, they can be provided only through diet (Blomhoff et al. 1991) and are crucial for vision, growth, bone development, reproductive success, immune function, normal differentiation and proliferation of cells, and 
maintenance of the general health of the organism (Wolf 1984, Favennec \& Cals 1988, Blomhoff 1994). Retinoid deficiency is associated with a diversity of anomalies, such as reproductive impairment, embryonic mortality, growth retardation, and decreased resistance to infections (Thompson 1976, Peakall 1992). These symptoms are similar to those that some environmental pollutants, particularly PCBs, dioxins (2, 3, 7, 8-tetrachlorodibenzop-dioxin: TCDDs) and DDTs, produce in mammals (Arnold et al. 1995, Colborn \& Smolen 1996), including marine mammals (Busbee et al. 1999, Respess et al. 1999). Therefore, retinoid deficiency may also enhance the toxicity of these compounds.

Traditionally, disruption of body retinoids has been assessed through plasma levels in terrestrial (Brouwer \& Van der Berg 1986, Bank et al. 1989, Brouwer et al. 1989a, Håkansson et al. 1991, Käkelä et al. 1999) and marine mammals (Brouwer et al. 1989b, De Swart et al. 1994, Jenssen et al. 1995, 2003, Beckmen et al. 1997, Simms et al. 2000, Skaare et al. 2001, Nyman et al. 2003). However, their concentration in plasma is, in general, regulated homeostatically (Wolf 1984, Blomhoff et al. 1992). Thus, plasma may not represent a stable measure of retinoid body deficit and is therefore of limited diagnostic use. Body retinoid status should be assessed through concentration in other tissues (Borrell et al. 2002).

Exposure of experimental animals, such as rats, mink and otters, to organochlorines leads to depletion of hepatic retinoid levels (Brunström et al. 1991, Håkansson et al. 1992, Chu et al. 1995, 1998, Murk et al. 1998, Käkelä et al. 1999, 2002, 2003, Kelley et al. 2000), while those in the kidney generally increase (Brouwer et al. 1989a, Jurek et al. 1990, Nilsson et al. 2000). This indicates that the pollutants mobilize retinoid storage forms, which is followed by an increase in their degradation and renal elimination through the urine (Kelley et al. 1998, 2000). Study on the disruption of retinoids induced by pollutants in tissues other than plasma in marine mammals is restricted to the work of Nyman et al. (2003). They found that increasing concentrations of PCBs and DDTs led to a significant decrease in hepatic retinoids of ringed seals Phoca hispida and grey seals Halichoerus grypus.

Body distribution of retinoids has not been studied in detail. In terrestrial mammals, the liver holds 70 to $90 \%$ of total body retinoids (Wolf 1984). In marine mammals, information is practically restricted to pinnipeds. In grey, ringed, harbour (Phoca vitulina), and harp seals Pagophilus groenlandicus, the liver presented the highest retinoid concentrations, although those of the blubber were also elevated (Rodahl \& Davies 1949, Schweigert et al. 1987, Schweigert \& Buchholz 1995, Käkelä et al. 1997, Mos \& Ross 2002, Schweigert et al. 2002, Nyman et al. 2003). Lower concentrations are found in other tissues, such as kidney, lung, retina, pancreas, skin and spleen (Rodahl \& Davies 1949, Schweigert \& Buchholz 1995, Mos \& Ross 2002). In cetaceans, data on retinoid concentrations are available only for some tissues, but results are not comparable between studies because of significant variation at individual, population and species levels. The liver of cetaceans is also extremely rich in retinoids (SchmidtNielsen et al. 1934), and several decades ago researchers studied hepatic concentrations in large whales with the aim to industrially extract Vitamin A from them (Klem 1935, Wetlesen 1938, Wagner 1939, Braekkan 1948, Ishikawa et al. 1948, 1951, Kaneko 1948, Mori \& Saiki 1950, Tawara \& Fukazawa 1950a,b). Other tissues have received little attention. Mori \& Saiki (1950) measured retinoid concentrations in the blubber and intestine of sperm whales Physeter macrocephalus, Gregory et al. (1955) in the milk of blue whales Balaenoptera musculus, Rosas \& Lehti (1996) in the milk of Amazon river dolphins Inia geoffrensis, Iida et al. (1998) in the muscle and blubber of minke whales Balaenoptera acutorostrata, and Borrell et al. (1999) in the blubber of harbour porpoises Phocoena phocoena. The scarce information on blubber retinoid in cetaceans is surprising, as this tissue can easily be sampled using non-destructive biopsy techniques (Aguilar \& Borrell 1994).

Here we studied retinoid distribution in the main body components of common dolphins Delphinus delphis in order to evaluate the representativeness of the various tissues in the assessment of body retinoid status in cetaceans. We also examined the effects of sex, body size and blubber lipid content on retinoid concentrations in these tissues.

\section{MATERIALS AND METHODS}

Sample collection. We examined and sampled 21 common dolphin carcasses (11 males and 10 females) that were incidentally caught by fishing boats in northwestern waters of Spain in 2001 and 2002. Necropsies were performed onboard no more than $12 \mathrm{~h}$ post mortem. Thus, the individuals sampled were fresh and were considered to be representative of the population. Dolphins were measured and sexed, and samples of liver, kidney, lung, heart, muscle, and blubber were collected from each individual. Blubber samples were excised from the region posterior to the dorsal fin. To avoid the potential effect of lipid stratification on retinoid concentrations (Aguilar \& Borrell 1990), each sample was carefully taken to include all blubber layers, from the skin to the fascia adjacent to the muscle. The various body components of 1 of the dolphins was carefully excised and weighed separately to calculate total body retinoid loads. All samples for retinoid 
determinations were transported to the laboratory on dry ice and stored in darkness at $-20^{\circ} \mathrm{C}$ until analysis.

Chemical analysis. For retinoid analysis, samples were treated at room temperature and under red light. The samples, which weighed ca. $100 \mathrm{mg}$ each, were saponified overnight in an ethanolic $\mathrm{KOH}$ solution $(1 \mathrm{~g}$ $\mathrm{KOH}, 2 \mathrm{ml}$ distilled $\mathrm{H}_{2} \mathrm{O}, 2 \mathrm{ml}$ ethanol, $20 \mathrm{mg}$ ascorbic acid) in a mechanical shaker under a nitrogen atmosphere. Retinoids (retinol and retinyl esters) were extracted by adding $8 \mathrm{ml}$ diethyl ether and shaking for $30 \mathrm{~min}$. After separation from the aqueous phase, an internal standard (retinyl acetate) was added and the organic extract was cleaned 3 times with $4 \mathrm{ml}$ of aqueous phosphate buffer ( $\mathrm{pH}$ 7.4). The extract was dried under nitrogen and reconstituted with $1 \mathrm{ml}$ methanol and $0.05 \%$ butylated hydroxy toluene (BHT) as antioxidant. Reconstituted samples were filtered $(0.20 \mu \mathrm{m}$ mesh) and a $20 \mu \mathrm{l}$ subsample was injected automatically (Waters 700 Satellite wisp) into a HPLC (Waters 600 E System Controller Pump) equipped with a Restek column (Tracer Excel 120 ODS-A, $10 \mathrm{~cm}$ length, $5 \mu \mathrm{m}$ beds, $0.46 \mathrm{~cm}$ internal diameter) and a UV detector (Waters 486 Tuneable absorbance D) set at $326 \mathrm{~nm}$. The retinoid was eluted at a flow rate of $1 \mathrm{ml} \mathrm{min} \mathrm{m}^{-1}$ using a mobile phase of methanol/water (80/20 by volume) for $1 \mathrm{~min}$, followed by a linear gradient of $3 \mathrm{~min}$ to $100 \%$ methanol for $14 \mathrm{~min}$.

For lipid content analyses of blubber samples, a subsample of the tissue was extracted with methanol-chloroform (Folch et al. 1957). Tissue lipid content was determined gravimetrically from the extract and expressed as a percentage of the tissue fresh weight (blubber lipid content, BLC\%).

Calculation of retinoid load. One dolphin was thoroughly necropsied by excising the main body tissues, which were then weighed separately. The total amount (load) of retinoids in each tissue was calculated by multiplying its weight by its retinoid content, as determined by the analysis of a subsample. Total body retinoid load was estimated by addition of the tissue.

Statistical analysis. The analysis aimed at investigating systematic differences in retinoid concentration between different tissues (liver, kidney, heart, muscle, lung, and dorsal blubber), but nutritive condition (as measured by lipid content), sex and individual effects were other potential sources of retinoid variability. Therefore, in order to model variability in retinoids as predicted by these variables, we considered tissue as the main experimental factor, and sex, lipids and individual as potential covariates.

In usual linear models, individual effects would be treated as factors in which each dolphin would be a different level. However, such complex models were not supported by our sample size. Instead, we considered individual variability as random deviates of the population mean. In this way, different organ effects modelled across dolphins were considered to be fixed or population mean effects, and individual deviates from the population mean were considered to be random effects. Thus, we modelled variability in retinoid concentration using linear mixed-effects models (Pinheiro \& Bates 2000). Retinoid concentration was transformed to natural logarithm scale to reduce the large differences between the concentration in liver and the rest of the tissues and to normalise the data.

Models with different combinations of predicting variables were fitted to investigate the main source of variability in retinoids. The modelling also considered different variance functions to reduce heteroscedasticy, and thus improve the fit and the assessment of variability. To test assumptions about covariate effects and homoscedasticity, we used the Akaike's information criterion (AIC) (Burnham \& Anderson 1998) and ANOVA methods specifically developed for mixedeffects model comparisons (Pinheiro \& Bates 2000). Models with comparably lower AIC provided the best fit in terms of a good compromise between model parsimony and a good description of the data.

\section{RESULTS}

Body lengths ranged between 176 and $207 \mathrm{~cm}$ $($ mean $=195.1 \mathrm{~cm})$ in males and 176 and $206 \mathrm{~cm}$ (mean $=190.6 \mathrm{~cm}$ ) in females (Table 1), which indicates that our sample was mostly composed of adult animals

Table 1. Delphinus delphis. Date of capture, sex and length. M: male; F: female; RIV: Riveira (sampling location)

\begin{tabular}{|lccc|}
\hline Dolphin & Date (dd/mm/yy) & Sex & Length $(\mathrm{cm})$ \\
\hline RIV 2001-1 & $28 / 03 / 01$ & $\mathrm{M}$ & 187 \\
RIV 2001-2 & $11 / 07 / 01$ & $\mathrm{M}$ & 202 \\
RIV 2001-3 & $11 / 07 / 01$ & $\mathrm{M}$ & 206 \\
RIV 2001-4 & $18 / 07 / 01$ & $\mathrm{~F}$ & 189 \\
RIV 2001-5 & $19 / 07 / 01$ & $\mathrm{~F}$ & 179 \\
RIV 2001-6 & $17 / 07 / 01$ & $\mathrm{~F}$ & 197 \\
RIV 2001-7 & $23 / 07 / 01$ & $\mathrm{M}$ & 204 \\
RIV 2001-10 & $23 / 07 / 01$ & $\mathrm{M}$ & 208 \\
RIV 2001-13 & $23 / 07 / 01$ & $\mathrm{M}$ & 190 \\
RIV 2002-14 & $04 / 07 / 02$ & $\mathrm{~F}$ & 176 \\
RIV 2002-15 & $18 / 07 / 02$ & $\mathrm{~F}$ & 206 \\
RIV 2002-16 & $18 / 07 / 02$ & $\mathrm{~F}$ & 187 \\
RIV 2002-17 & $18 / 07 / 02$ & $\mathrm{~F}$ & 180 \\
RIV 2002-23 & $25 / 07 / 02$ & $\mathrm{~F}$ & 200 \\
RIV 2002-18 & $31 / 01 / 02$ & $\mathrm{M}$ & 176 \\
RIV 2002-20 & $31 / 07 / 02$ & $\mathrm{M}$ & 207 \\
RIV 2002-21 & $31 / 07 / 02$ & $\mathrm{M}$ & 183 \\
RIV 2002-22 & $31 / 07 / 02$ & $\mathrm{M}$ & 182 \\
RIV 2002-24 & $31 / 07 / 02$ & $\mathrm{M}$ & 201 \\
RIV 2002-19 & $22 / 08 / 02$ & $\mathrm{~F}$ & 194 \\
RIV 2002-25 & $10 / 09 / 02$ & $\mathrm{~F}$ & 198 \\
& & & \\
\hline
\end{tabular}


(Collet 1981). Individual retinoid values ranged from concentrations below analytical detection limit for heart and lung to $460 \mathrm{\mu g} \mathrm{g}^{-1}$ for liver, while mean values ranged between 1.5 and $134{\mu g^{-1}}^{-1}$, with extreme figures for lung and liver, respectively (Table 2).

The largest variation in mean retinoid concentration (unmodelled) was between different tissues, and the lowest variation was by sex (Fig. 1). Individual variation was moderate in comparison, but the boxplot of the residuals (Fig. 2) of mixed-effects models (Table 3 ; Model 6) highlighted individual variability and outlier effects. The residuals were centred at zero, indicating a relatively good model fit, but also a larger variability in males than in females.

Models allowing different variances first by tissue and by sex reduced heteroscedasticity (Table 3; Mod-

Table 2. Delphinus delphis. Mean, associated SD and ranges of retinoid concentrations in the tissues of the dolphins examined. Concentrations are expressed as $\mu \mathrm{g} \mathrm{g}^{-1}$ calculated in relation to the fresh weight of the tissue. nd: not detected

\begin{tabular}{|lrrrrr|}
\hline \multirow{2}{*}{ Tissue } & \multirow{2}{*}{$\mathrm{n}$} & \multicolumn{5}{c}{ Retinoid concentration } \\
\cline { 3 - 6 } & & Mean & SD & Max. & Min. \\
\hline Liver & 21 & 134.13 & 131.76 & 459.68 & 14.94 \\
Blubber & 21 & 41.38 & 13.43 & 70.86 & 23.47 \\
Kidney & 21 & 7.76 & 4.05 & 15.92 & 1.91 \\
Muscle & 21 & 2.98 & 3.29 & 13.21 & 0.78 \\
Heart & 20 & 2.06 & 2.39 & 10.94 & nd \\
Lung & 21 & 1.51 & 1.09 & 4.71 & nd \\
\hline
\end{tabular}

els 2 and 3), and also reduced the number and dispersion of outliers towards normality. A model with different variance by sex fit less well than a model with different variance by tissue, suggesting that individual deviations from the mean retinoid concentration in tissues masked possible sex effects. Therefore, the next comparisons were based on models with different variance by tissue, including different covariates as independent linear predictors of retinoid concentration.

Model 6, which had blubber lipid content as a covariate, provided a significant improvement in relation to Model 2, as shown by a lower AIC. Although the explanatory power of the 2 models was comparable, the latter result was in agreement with the lipophilic nature of retinoids, suggesting that retinoid concentration was strongly related to lipid content.

Models 4 and 5, with sex and body size as covariates respectively, did not provide a better fit than Model 6, but a model with sex, lipid content and the interaction between the 2 (Model 8) provided the best fit among models. The ANOVA tests for this model indicated that differences in retinoid concentration were highly significant between tissues $(F=219.640$; df $=5$; p < $0.0001)$, that retinoid covaried with lipid content $(F=$ $6.440 ; \mathrm{df}=1 ; \mathrm{p}=0.0219$ ), and that the interaction between sex and lipid content affected retinoid concentration $(F=8.134$; df $=1 ; \mathrm{p}=0.0115)$.

The maximum likelihood estimates of variance components $(\hat{\sigma})$ were 0.111 for between-dolphin variation ( $\hat{\sigma}$, approximately $95 \% \mathrm{CI}$ : 0.034 to 0.368 ) and

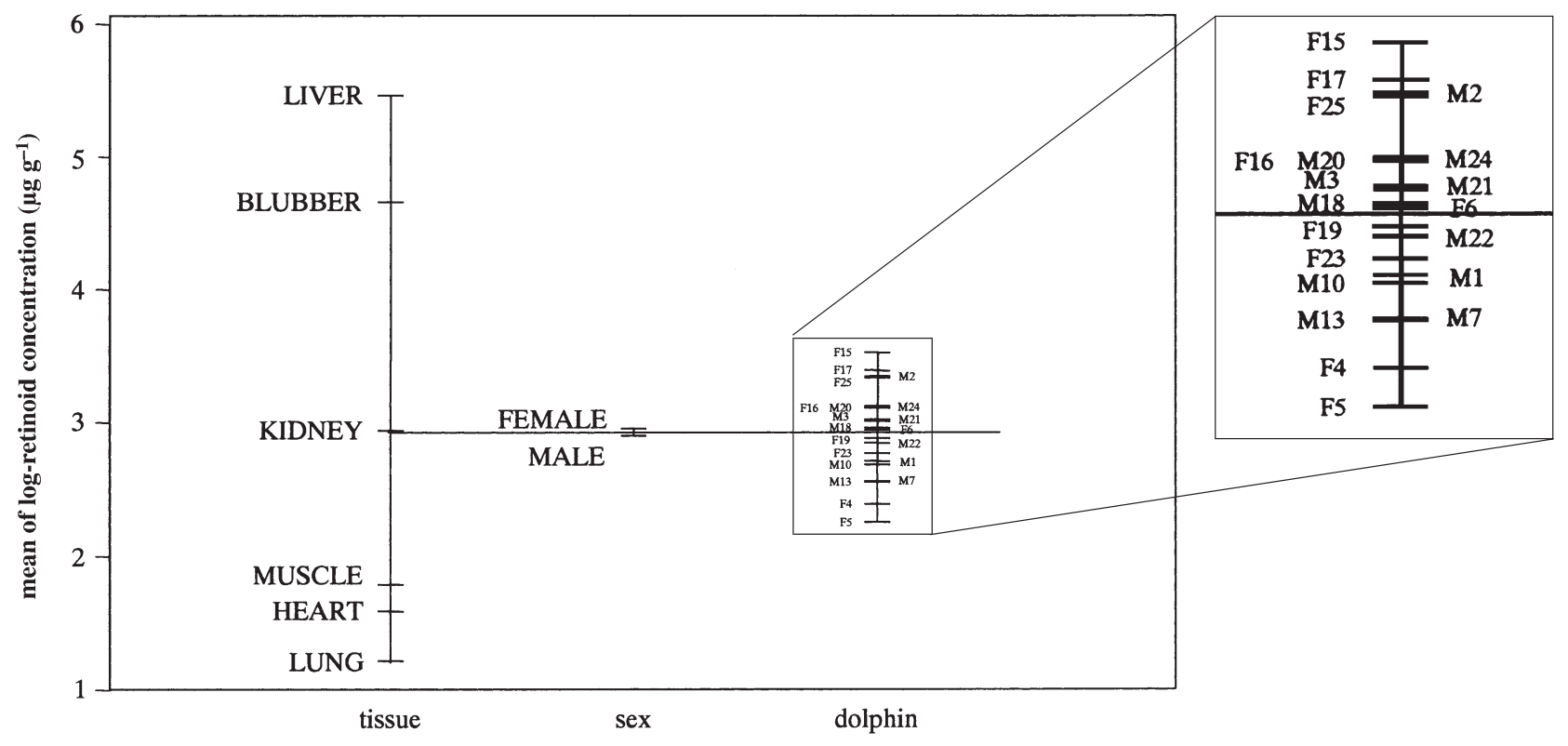

Factors

Fig. 1. Delphinus delphis. Variation in mean log-retinoid concentration $\left(\mu \mathrm{g} \mathrm{g}^{-1}\right)$ among tissues, sexes and dolphins 
FEMALE

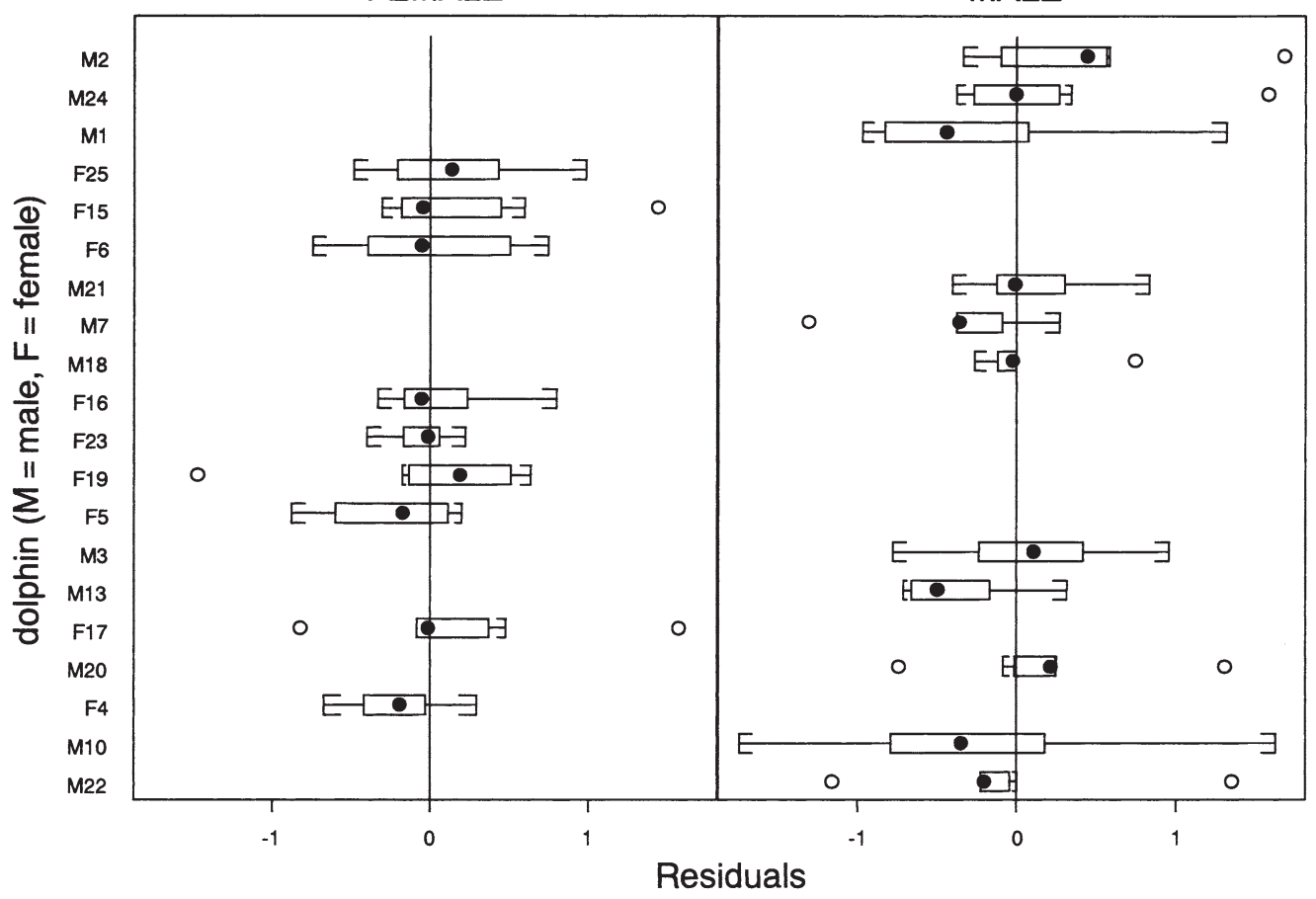

Fig. 2. Delphinus delphis. Boxplot of the residuals by individual dolphin and split by sex, with outliers as open circles; resulting from the fit of model 1

Table 3. Delphinus delphis. Mixed-effects model selection and testing. The basic model (1) is as Eq. (1) (see text) and more complicated models add structure to the variance model and additional covariates sex $(S)$, body size $(B S)$, and the overall lipid content $(L P)$ of retinoid variation. Model testing is based on ANOVA methods specifically developed for mixed-effects models (Pinheiro \& Bates 2000). In this test, a p-value below 0.05 indicates a significantly better fit of the model with more structure, i.e. larger df. In the model notation $\alpha_{j}$ was the population mean retinoid concentration, also known as fixed effects; $b_{i}$ was a random variable representing the deviation from the population mean $\alpha_{j}$ of the mean retinoid concentration in the ith dolphin, also known as random effects; $\varepsilon_{i j}$ was the residual variance, which measured unexplained within-dolphin variability in retinoid concentration among tissues; $\beta_{i}$ represents the effect corresponding to the covariate name. Heteroscedasticity was modelled using different residual variance functions. These functions considered different variability for different tissues and sex; for instance, for sex, $\operatorname{var}\left(\varepsilon_{i j}\right)=\sigma^{2} \delta^{2}$ sex with a different variance parameter $\delta_{l}$ corresponding to each of the 1 sexes. Interactions between covariates, for instance, between sex and lipid content, are noted as LP-in-S. Df: degrees of freedom; AIC: Akaike's information criterion;

LogL: Model log-likelihood; LRT: likelihood ratio statistic; Test: indicates which models are compared

\begin{tabular}{|c|c|c|c|c|c|c|}
\hline Model & df & $\mathrm{AIC}$ & $\log L$ & Test & LRT & $\mathrm{p}$ \\
\hline $1 y_{i j}=\alpha_{j}+b_{i}+\varepsilon_{i j}$ & 8 & 259.60 & -121.80 & & & \\
\hline $2 y_{i j}=\alpha_{j}+b_{i}+\varepsilon_{i j,} \operatorname{var}\left(\varepsilon_{i j}\right)=\sigma^{2} \delta_{\text {tissue }}^{2}$ & 13 & 242.71 & -108.35 & 1 vs 2 & 26.89 & 0.0001 \\
\hline $3 y_{i j}=\alpha_{j}+b_{i}+\varepsilon_{i j,} \operatorname{var}\left(\varepsilon_{i j}\right)=\sigma^{2} \delta_{\text {sex }}^{2}$ & 9 & 260.57 & -121.29 & $\begin{array}{l}2 \text { vs } 3 \\
1 \text { vs } 3\end{array}$ & $\begin{array}{r}25.87 \\
1.03\end{array}$ & $\begin{array}{r}<0.0001 \\
0.3104\end{array}$ \\
\hline $4 \quad y_{i j}=\alpha_{j}+b_{i}+\beta_{i} S_{i j}+\varepsilon_{i j}, \operatorname{var}\left(\varepsilon_{i j}\right)=\sigma^{2} \delta_{\text {tissue }}^{2}$ & 14 & 244.65 & -108.33 & 2 vs 4 & 0.06 & 0.8117 \\
\hline $5 \quad y_{i j}=\alpha_{j}+b_{i}+\beta_{i} B S_{i j}+\varepsilon_{i j}, \operatorname{var}\left(\varepsilon_{i j}\right)=\sigma^{2} \delta_{\text {tissue }}^{2}$ & 14 & 243.07 & -107.54 & 2 vs 5 & 1.63 & 0.2016 \\
\hline$y_{i j}=\alpha_{j}+b_{i}+\beta_{i} L P_{i j}+\varepsilon_{i j,} \operatorname{var}\left(\varepsilon_{i j}\right)=\sigma^{2} \delta_{\text {tissue }}^{2}$ & 14 & 240.44 & -106.22 & 2 vs 6 & 4.27 & 0.0389 \\
\hline $7 \quad y_{i j}=\alpha_{j}+b_{i}+\beta_{i} L P_{i j}+\beta_{i} B S_{i j}+\varepsilon_{i j,} \operatorname{var}\left(\varepsilon_{i j}\right)=\sigma^{2} \delta_{\text {tissue }}^{2}$ & 15 & 241.97 & -105.98 & 6 vs 7 & 0.47 & 0.4917 \\
\hline $8 \quad y_{i j}=\alpha_{j}+b_{i}+\beta_{i} S_{i j}+\beta_{i} L P_{i j}+\beta_{i} L P-i n-S_{i j}+\varepsilon_{i j,} \operatorname{var}\left(\varepsilon_{i j}\right)=\sigma^{2} \delta_{\text {tissue }}^{2}$ & 16 & 237.34 & -102.67 & $\begin{array}{l}6 \text { vs } 8 \\
1 \text { vs } 8\end{array}$ & $\begin{array}{r}7.10 \\
11.34\end{array}$ & $\begin{array}{l}0.0287 \\
0.0099\end{array}$ \\
\hline $9 y_{i j}=\alpha_{j}+b_{i}+\beta_{i} L P$-in- $S_{i j}+\varepsilon_{i j}, \operatorname{var}\left(\varepsilon_{i j}\right)=\sigma^{2} \delta_{\text {tissue }}^{2}$ & 15 & 241.93 & -105.97 & $\begin{array}{l}6 \text { vs } 9 \\
8 \text { vs } 9\end{array}$ & $\begin{array}{l}0.51 \\
6.59\end{array}$ & $\begin{array}{l}0.4753 \\
0.0102\end{array}$ \\
\hline
\end{tabular}

0.996 of within-dolphin variation $(\hat{\sigma}$, approximately $95 \%$ CI: 0.725 to 1.368$)$. These estimates confirmed that a higher variability in retinoid concentration was explained by differences between tissues, rather than additional covariates or individual differences. How- ever, the large confidence interval of $\hat{\sigma}$ highlighted the effects of a few dolphins, mostly males, with extreme differences in values of retinoids. For instance, dolphin RIV 2001-1 had a total body retinoid load estimated at $1306 \mathrm{mg}$ (Table 4). Considering this 
Table 4. Delphinus delphis. Weights (kg), retinoid concentrations $\left(\mu \mathrm{g} \mathrm{g}^{-1}\right)$ and loads $(\mathrm{mg})$ of the main body tissues of the common dolphin RIV2001-1

\begin{tabular}{|lrrrrrrr|}
\hline & Blubber & Liver & Muscle & Kidney & Lung & Heart \\
\hline Weight & 22.34 & 2.2 & 34.87 & 3.4 & 3.2 & 0.9 & Total \\
Retinoid concentration & 25.21 & 319.18 & 0.78 & 2.67 & 0.77 & 2.26 \\
Retinoid load & 563.19 & 702.20 & 27.20 & 9.08 & 2.46 & 2.03 & 1306 \\
\% of total retinoids & 43.12 & 53.76 & 2.08 & 0.69 & 0.19 & 0.16 & 100 \\
\hline
\end{tabular}

value as $100 \%$, it was calculated that the body tissues stored from $53 \%$ (liver) to $0.16 \%$ (heart) of retinoid body load.

\section{DISCUSSION}

We found that variability among organs within the same individual was much higher than among distinct individuals for the same organ. Consequently, the choice of tissue to monitor retinoids in common dolphins is a central issue.

As established for most terrestrial and marine mammals, the liver presented the highest retinoid concentrations; However, interspecific variation was large. The concentrations found were lower than those found in the liver of other cetacean species, such as blue, fin (Balaenoptera physalus) and sperm whales (SchmidtNielsen et al. 1934, Klem 1935, Wagner 1939, Braekkan 1948). In comparison to other marine mammals, our concentrations were higher than those reported for harbour and freshwater ringed seals (Rodahl \& Davies 1949, Käkelä et al. 1997, Mos \& Ross 2002), similar to those in hooded and marine ringed seals and California sea lions Zalophus californianus (Rodahl \& Davies 1949, Ball et al. 1992, Käkelä et al. 1997), and lower than those reported for harp, grey, fur (Arctocephalus pusillus doriferus) and bearded seals Erignathus barbatus and polar bears Ursus maritimus (Rodahl \& Moore 1943, Rodahl \& Davies 1949, Southcott et al. 1974, Ball et al. 1986, Schweigert et al. 1987, 2002).

Although these high concentrations of retinoids in principle suggest that the liver may provide an important measure of body retinoid status, the contribution of this organ to total retinoid reserves in common dolphins was estimated to be only $53 \%$, while in terrestrial mammals it accounts for up to $90 \%$ (Blomhoff 1994). It should be taken into account that the retinoid load of liver, as well as those of the other analysed tissues, was obtained from only 1 common dolphin and, therefore, the obtained values must be interpreted with caution. In addition to this, liver is not a practical tissue for monitoring free-ranging populations as it requires the capture, immobilization and handling of the individual, and the use of highly invasive biopsy techniques or, alternatively, necropsy when the individual is sacrificed or found dead.

In mammals, kidneys constitute another large reserve for retinoids (Bomhoff et al. 1991). Kidney values for common dolphins were similar to those found in grey seals (Rodahl \& Davies 1949, Schweigert et al. 2002) and higher than those in harp seals (Rodahl \& Davies 1949). Nevertheless, all kidney concentrations were several orders of magnitude lower than those of the liver and, occasionally, almost bordered analytical detection limits. The retinoid concentrations in the muscle, lung, and heart of the common dolphins were also insignificant compared to those of the liver. The contribution of these 4 tissues to the total retinoid load was lower than $4 \%$; therefore, none appear to be representative of retinoid status in marine mammals.

As retinoids are fat-soluble, they accumulate in lipidrich tissues. Blubber is the fattest compartment in marine mammals and it has been proposed that this tissue is an important body depot for retinoids in pinnipeds (Schweigert et al. 1987, 2002, Käkelä et al. 1997). In cetaceans, information is more limited, but the high blubber retinoid levels found in the present study, and those reported in a similar study on harbour porpoises (Borrell et al. 1999), are comparable to those found in grey seals (Schweigert et al. 1987, 2002, Schweigert \& Buchholz 1995, Nyman et al. 2003) and ringed seals (Käkelä et al. 1997), but much higher than those reported in harp seals (Rodahl \& Davies 1949).

Blubber constitutes a significant proportion of the total body mass of marine mammals, approximately $40 \%$ in pinnipeds (Schweigert et al. 1987) and 15 to $45 \%$ in cetaceans (Aguilar et al. 1999). Consequently, although blubber retinoid concentrations are lower than those in liver, the contribution of the former to the total retinoid reserves is comparatively as high as that of the latter. Schweigert et al. (1987) and Mos \& Ross (2002) determined that ca. 40 and $66 \%$ of body retinoids were stored in the blubber of grey and harbour seals, respectively. In the common dolphin studied here, blubber was estimated to contribute $43 \%$ of body retinoids, although this is probably an underestimate because the blubber location sampled (posterior to the 
dorsal fin) is likely to contain slightly lower retinoid concentrations than other blubber regions (Tornero et al. 2004). Given that blubber can be readily obtained from both free-ranging and captured individuals using biopsy techniques (Aguilar \& Borrell 1994), we propose blubber as a tissue of choice for monitoring retinoid status in delphinid populations.

However, blubber is a massive compartment that covers the whole body surface of cetaceans and presents substantial heterogeneities in structure and composition between body sites (Iverson 2002). In a previous study, Tornero et al. (2004) found significant within-blubber topographical variation in retinoid concentrations in common dolphins. Protocols for monitoring retinoids through this tissue must ensure consistency in body sample location to guarantee comparability of results.

In all large cetacean species, and independently of body location, blubber presents a stratified structure that reflects the various functions of the distinct layers (Lockyer et al. 1985, Aguilar \& Borrell 1990, Lockyer 1991). Because blubber thickness in these animals can be between 3 and $50 \mathrm{~cm}$ depending on the species (Iverson 2002), representative sampling is difficult because only a few grams of the blubber thickness can be used in the analysis. However, in small cetaceans, such as common dolphins, this effect is limited (Koopman et al. 1996) and can be easily overcome by collecting and analysing sections of blubber that contain all blubber layers, as in the procedure followed in the present study.

Blubber lipid content (BLC) was a strong determinant of overall retinoid concentration. We found a positive relationship between retinoid concentration and BLC, which is in agreement with Tornero et al. (2004). The body distribution of retinoids is significantly affected by the physicochemical properties of their molecules; thus, not only do retinoids concentrate in lipid-rich tissues, but also their concentration within a given tissue is proportional to the lipid content of this tissue. However, this relationship was not observed by Rodahl \& Davies (1949) in hooded seals Cystophora cristata and harp seals, by Borrell et al. (1999) in harbour porpoises, or by Mos \& Ross (2002) in harbour seal pups. Lactation, migration, disease and other factors cause the mobilization of lipids and, presumably, that of the blubber-associated retinoid reserves. In these situations, retinoids may be either redistributed or excreted, and significant variation in tissue concentrations is expected. Consequently, stranded cetaceans, which are often in poor nutritive condition, are a poor sample group to assess retinoid status of populations because they are likely to show altered retinoid values.

Other individual traits (e.g. age, sex, diet, pollutant concentrations) also generate variability in retinoid status (Borrell et al. 2002). We did not find significant differences in retinoid concentrations between males and females for any of the tissues, which is in agreement with the results obtained by Borrell et al. (1999) in blubber of harbour porpoises and by Mos \& Ross (2002) in blubber of young harbour seals. However, Schweigert et al. (1987) and Nyman et al. (2003) found sex-related differences in blubber of adult grey seals and harbour seals, respectively. Rodahl \& Davies (1949), Southcott et al. (1974) and Schweigert et al. (1987) also reported these differences in the liver of hooded, harp, fur and grey seals. Taxonomic, dietary, life-cycle and reproductive status dissimilarities between the individuals sampled could explain these sex-related variations; However, we found that the interaction between sex and lipid content affected tissue retinoid concentration. This appears to indicate that the relationship between retinoid levels and BLC in males and females differs. Reproductive activity may explain this difference, as it often involves changes in behavioral traits and diet. Further research into the influence of factors or conditions (age, sex, reproductive condition, diet) inducing variation in retinoid status and deposition in blubber is required to implement the use of retinoids as biomarkers of pollutant exposure in cetaceans.

Acknowledgements. Fieldwork was possible thanks to the assistance of collaborating biologists, in particular M. M. Fernández, E. Pubill, N. García, G. Julián, and J. Gonzalvo. The authors thank the skippers and crew of the fishing boats on which the sampling was performed, particularly A. Martínez, J. Pérez and M. Abraldes. Samples were supplied by the BMA environmental tissue bank, created with the support of the PEW Fellows Program in Marine Conservation and Earthtrust. While doing this work, V.T. was supported by an FPI fellowship from the 'Generalitat de Cataluña', and A.B. by a contract under the 'Ramón y Cajal' program. Field and laboratory work was funded by the 'Comisión Interministerial de Ciencia y Tecnología-CICYT' (Project AMB 99-0640), 'Fundació pel Desenvolupament Sostenible (FDS)', and the General Directorate for Nature Conservation of the Spanish Ministry of the Environment.

\section{LITERATURE CITED}

Aguilar A, Borrell A (1990) Patterns of lipid content and stratification in the blubber of fin whales (Balaenoptera physalus). J Mamm 71:544-554

Aguilar A, Borrell A (1994) Assessment of organochlorines pollutants in cetacean by means of skin and hypodermic biopsies. In: Fossi MC, Leoncio C (eds) Nondestructive biomarkers in vertebrates. Lewis Publishers, Boca Raton, FL, p 245-267

Aguilar A, Borrell A, Pastor T (1999) Biological factors affecting variability of persistent pollutant levels in cetaceans. J Cetacean Res Manag (Spec Issue) 1:83-116

Arnold D, Bryce F, McGuire P, Stapley R and 6 others (1995) Toxicological consequences of Aroclor 1254 ingestion by female rhesus (Macaca mulatta) monkeys. Part 2. Reproduction and infant findings. Food Chem Toxicol 33:457-474

Ball MD, Furr HC, Olson JA (1986) Acyl coenzyme A: retinol acyltransferase activity and the vitamin A content of polar bear (Ursus maritimus). Comp Biochem Physiol B 84: $513-517$ 
Ball MD, Nizzi CP, Furr HC, Olson JA, Oftedal OT (1992) Fatty-acyl esters of retinol (Vitamin A) in the liver of the harp seal (Phoca groenlandica), hooded seal (Cystophora cristata), and California sea lion (Zalophus californianus). Biochem Cell Biol 70:809-813

Bank PA, Cullum ME, Jensen RK, Zile MH (1989) Effect of hexachlorobiphenyl on vitamin A homeostasis in the rat. Biochem Biophys Acta 990:306-314

Beckmen KB, Lowenstine LJ, Newman J, Hill J, Hanni K, Gerber J (1997) Clinical and pathological characterisation of northern elephant seal skin disease. J Wildl Dis 33: $438-449$

Blomhoff $\mathrm{R}$ (1994) Overview of vitamin A metabolism and function. In: Blomhoff R (ed) Vitamin A in health and disease. Marcel Dekker, New York, p 1-35

Blomhoff R, Green MH, Green JB, Berg T, Norum KR (1991) Vitamin A metabolism: new perspectives on absorption, transport, and storage. Physiol Rev 71:951-990

Blomhoff R, Green MH, Norum KR (1992) Vitamin A: physiological and biochemical processing. Annu Rev Nutr 12: $37-57$

Borrell A, Cantos G, Aguilar A, Lockyer C, Brouwer A, HeideJorgensen MP, Jensen J, Spenkelink B (1999) Patterns of variability of retinol levels in a harbour porpoise population from an unpolluted environment. Mar Ecol Prog Ser 185:85-92

Borrell A, Tornero V, Aguilar A (2002) Retinoids in marine mammals and their use as biomarkers of organochlorine compounds. J Cetacean Res Manag 4:203-211

Braekkan OR (1948) Vitamins in whale liver. Sci Res Mar Biol Res 32:1-25

Brouwer A, Van den Berg KJ (1986) Binding of a metabolite of $3,4,3^{\prime}, 4^{\prime}$-tetrachlorobiphenyl to transthyretin reduces serum vitamin A transport by inhibiting the formation of the protein complex carrying both retinol and thyroxin. Toxicol Appl Pharmacol 85:301-312

Brouwer A, Håkansson H, Kukler A, Van Den Berg KJ, Ahlborgg UG (1989a) Marked alterations in retinoid homeostasis of Sprague-Dawley rats induced by a single i.p dose of $10 \mathrm{ug} / \mathrm{Kg}$ of 2,3,7,8-tetrachlorodibenzo-pdioxin. Toxicology 58:267-283

Brouwer A, Reijnders PJH, Koeman JH (1989b) Polychlorinated biphenyl (PCB)-contaminated fish induces vitamin $A$ and thyroid hormone deficiency in the common seal (Phoca vitulina). Aquat Toxicol 15:99-106

Brunström B, Håkansson H, Lundberg K (1991) Effects of a technical PCB preparation and fractions thereof on ethoxyresorufin O-deethylase activity, vitamin A levels and thymic development in the mink (Mustela vison). Pharmacol Toxicol 69:421-426

Burnham KP, Anderson DR (1998) Model selection and inference. A practical information-theoretic approach. Springer-Verlag, New York

Busbee D, Tizard I, Stott J, Ferrick D, Ott-Reeves E (1999) Environmental pollutants and marine mammal health: the potential impact of hydrocarbons and halogenated hydrocarbons on immune system dysfunction. J Cetacean Res Manag Spec Issue 1:223-248

Chu I, Villeneuve DC, Yagminas A, Lecavalier P and 7 others (1995) Toxicity of PCB 77 (3,3',4,4'-tetrachlorobiphenyl) and PCB $118\left(2,3^{\prime}, 4,4^{\prime}, 5\right.$-pentachlorobiphenyl) in the rat following subchronic dietary exposure. Fundam Appl Toxicol 26:282-292

Chu I, Poon R, Yagminas A, Lecavalier P and 6 others (1998) Subchronic toxicity of PCB $105\left(2,3,3^{\prime}, 4,4^{\prime}\right.$-pentachlorobiphenyl) in rats. J Appl Toxicol 18:285-292

Colborn T, Smolen MJ (1996) Epidemiological analysis of persistent organochlorine contaminants in cetaceans. Rev Environ Contam Toxicol 146:91-172

Collet A (1981) Biologie du dauphin commun Delphinus delphis L. en Atlantique Nord-Est. PhD thesis, Université de Poitiers

Depledge MH, Fossi MC (1994) The role of biomarkers in environmental assessment. Invertebrates. Ecotoxicology 3:161-172

De Swart RL, Ross PS, Vedder LJ, Timmerman HH and 5 others (1994) Impairment of immune function in harbour seals (Phoca vitulina) feeding on fish from polluted waters. Ambio 23:155-159

Favennec L, Cals MJ (1988) The biological effects of retinoids on cell differentiation and proliferation. J Clin Chem Clin Biochem 26:479-489

Folch J, Lees M, Stanley GHS (1957) A simple method for the isolation and purification of total lipids from animal tissues. J Biol Chem 226:497-509

Gregory ME, Kon SK, Rowland SJ, Thompson SY (1955) The composition of the milk of the blue whale. J Dairy Res 22: 108-112

Håkansson H, Johansson L, Manzoor E, Ahlborg UG (1991) Effects of 2,3,7,8-tetrachlorodibenzo-p-dioxin (TCDD) on the vitamin A status of Hartley guinea pigs, SpragueDawley rats, C57B1/6 mice, DBA/2 mice and Golden Syrian hamsters. J Nutr Sci Vitaminol 37:239-255

Håkansson H, Manzoor E, Ahlborg UG (1992) Effects of technical PCB preparation and fractions thereof on vitamin A levels in the mink (Mustela vison). Ambio 21(8):588-590

Iida H, Murata Y, Matsumoto G, Toda S, Yamashita Y, Yokoyama M (1998) Chemical composition of the edible parts of minke whale Balaenoptera acutorostrata. Bull Nat Res Inst Fish Sci 11:27-36

Ishikawa S, Omote Y, Soma Y (1948) Analytical distillation of vitamin A in the whale liver oil. Sci Rep Whales Res Inst 2: 35-41

Ishikawa S, Omote Y, Okuda H (1951) Substances related to vitamin a in the whale liver oil. Sci Rep Whales Res Inst 5: $53-69$

Iverson SJ (2002) Blubber. In: Perrin WF, Würsig B, Thewissen JGM (eds) Encyclopedia of marine mammals. Academic Press, San Diego, p 107-112

Jenssen BM, Skaare JU, Woldstad S, Nastad AT, Haugen O, Kloven B, Sormo EG (1995) Biomarkers in blood to assess effects of polychlorinated biphenyls in free-living grey seal pups. In: Blix AS, Walloe L, Ulltang O (eds) Whales, seals, fish and man. Elsevier, Amsterdam, p 607-615

Jenssen BM, Haugen O, Sørmo EG, Skaare JU (2003) Negative relationship between PCBs and plasma retinol in lowcontaminated free-ranging grey seal pups (Halichoerus grypus). Environ Res 93:79-87

Jurek MA, Powers RH, Gilbert LG, Aust S (1990) The effect of TCDD on acyl coenzyme A:retinol acyltransferase activity and vitamin A accumulation in the kidney of male Sprague-Dawley rats. J Biochem Toxicol 5(3):155-160

Käkelä R, Hyvärinen H, Käkelä A (1997) Vitamins A-1 (retinol), A-2, $(3,4$ didehydroretinol) and $\mathrm{E}$ (alpha-tocophherol) in the liver and blubber of lacustrine and marine ringed seals (Phoca hispida sp.). Comp Biochem Physiol B 116:27-33

Käkelä R, Käkelä A, Hyvärinen H, Asikainen J, Dahl SK (1999) Vitamins A1, A2, and E in minks exposed to polychlorinated biphenyls (Aroclor $1242^{\circledR}$ ) and copper, via diet based on freshwater on marine fish. Environ Toxicol Chem 18:2595-2599

Käkelä A, Käkelä R, Hyvärinen H, Aiskainen J (2002) Vitamins A1 and A2 in hepatic tissue and subcellular fractions in mink feeding on fish-based diets and exposed to 
Aroclor 1242. Environ Toxicol Chem 21:397-403

Käkelä A, Käkelä R, Hyvärinen H, Nieminen P (2003) Effects of Aroclor 1242 and different fish-based diets on vitamins $\mathrm{A}_{1}$ (retinol) and $\mathrm{A}_{2}$ (3,4 didehydroretinol), and their fatty acyl esters in mink plasma. Environ Res 91:104-112

Kaneko A (1948) Molecular distillation of Fin whale liver oil. Sci Rep Whales Res Inst 2:46-50

Kelley S, Nilsson CB, Green MH, Green JB, Håkansson H (1998) Use of model-based compartmental analysis to study effects of 2,3,7,8-tetrachlorodibenzo-p-dioxin on vitamin A kinetics in rats. Toxicol Sci 44:1-13

Kelley S, Nilsson CB, Green MH, Green JB, Håkansson H (2000) Mobilisation of vitamin A stores in rats after administration of 2,3,7,8-tetrachlorodibenzo-p-dioxin: a kinetic analysis. Toxicol Sci 55:478-484

Klem A (1935) Studies on the biochemistry of whale oils. Hvalrad Skr 11:49-108

Koopman HN, Iverson SJ, Gaskin DE (1996) Stratification and age-related differences in blubber fatty acids of the male harbour porpoise (Phocoena phocoena). J Comp Physiol B 165:628-639

Lockyer CH (1991) Body composition of the sperm whale, Physeter catodon, with special reference to the possible functions of fat depots. Rit Fiskid 12:1-24

Lockyer CH, McConnell LC, Waters TD (1985) Body condition in terms of anatomical and biochemical assessment of body fat in North Atlantic fin and sei whales. Can J Zool 63:2328-2338

McCarthy F, Shugart LR (1990) Biomarkers of environmental contamination. Lewis Publishers, Chelsea, MI

Mori T, Saiki M (1950) Properties of fats and oils contained in various parts of a sperm whale body. Sci Rep Whales Res Inst 3:79-84

Mos L, Ross PS (2002) Vitamin A physiology in the precocius harbour seal (Phoca vitulina): a tissue-based biomarker approach. Can J Zool 80:1511-1519

Murk AJ, Leonards PEG, Van Hattum B, Luit R, Van der Weiden MEJ, Smit M (1998) Application of biomarkers for exposure and effect of polyhalogenated aromatic hydrocarbons in naturally exposed European otters (Lutra lutra). Environ Toxicol Pharmacol 6:91-102

Nilsson CB, Hoegberg P, Trossvik C, Azais-Braesco V and 7 others (2000) 2,3,7,8-tetrachlorodibenzo-p-dioxin increases serum and kidney retinoic acid levels and kidney retinol esterification in the rat. Toxicol Appl Pharmacol 169:121-131

NRC (National Research Council) (1989) Biologic markers in reproductive toxicology. National Academy Press, Washington, $\mathrm{DC}$

Nyman M, Bergknut M, Fant ML, Raunio H and 9 others (2003) Contaminant exposure and effects in Baltic ringed and grey seals as assessed by biomarkers. Mar Environ Res 55:73-99

O'Shea TJ, Aguilar A (2001) Cetaceans and sirenians. In: Shore RF, Rattner BA (eds) Ecotoxicology of wild mammals. Ecological and environmental toxicology series. John Wiley \& Sons, New York, p 427-496

Peakall D (1992) Animal biomarkers as pollution indicators. Ecotoxicological Series 1. Chapman \& Hall, London

Pinheiro JC, Bates DM (2000) Mixed effects models in S and S-Plus. Springer-Verlag, New York

Reijnders PJH, Aguilar A (2002) Pollution and marine mammals. In: Perrin WF, Würsig B, Thewissen JGM (eds) Encyclopedia of marine mammals. Academic Press, San Diego, CA, p 948-957
Respess DS, Carr RL, Cox NM, McCoy CP, Moore AB, Chambers JE (1999) Evaluation of the reproductive parameters in rates affected by the interactions of polychlorinated biphenyls and methoxychlor resulting from exposure during development. Toxicologist 48:374-375

Rodahl K, Davies AW (1949) Vitamin A in seals. Biochemistry 45:408-412

Rodahl K, Moore T (1943) The vitamin A content and toxicity of bear and seal liver. Biochemistry 37:166-168

Rolland RM (2000) A review of chemically-induced alterations in thyroid and vitamin A status from field studies of wildlife and fish. J Wildl Dis 36:615-635

Rosas FCW, Lehti KK (1996) Nutritional and mercury content of milk of the Amazon river dolphin, Inia geoffrensis. Comp Biochem Physiol A 115:117-119

Schmidt-Nielsen S, Flood A, Stene J (1934) Ueber grösse und vitamingehalt der leber verschiedener tiere. Kgl Nor Vidensk Selsk Forhandlinger 7:81

Schweigert FJ, Buchholz Y (1995) Vitamin A metabolism in carnivores with special reference to fur bearing animals. Scientifur 19:305-307

Schweigert FJ, Stobo WT, Zucker H (1987) Vitamin A status in the grey seal (Halichoerus grypus) on Sable Island. Int J Vit Nutr Res 57:239-245

Schweigert FJ, Luppertz M, Stobo WT (2002) Fasting and lactation effect fat-soluble vitamin $\mathrm{A}$ and $\mathrm{E}$ levels in blood and their distribution in tissue of grey seals (Halichoerus grypus). Comp Biochem Physiol A 131:901-908

Simms W, Ross PS (2000) Vitamin A physiology and its application as a biomarker of contaminant-related toxicity in marine mammals: a review. Toxicol Ind Health 16: 291-302

Simms W, Jeffries SJ, Ikonomou MG, Ross PS (2000) Contaminant-related disruption of vitamin A dynamics in freeranging harbor seal (Phoca vitulina) pups from British Columbia, Canada and Washington State, USA. Environ Toxicol Chem 19:2844-2849

Skaare JU, Bernhoft A, Wiig O, Norum KR, Haug E, Eide DM, Derocher AE (2001) Relationships between plasma levels or organochlorines, retinol and thyroid hormones from polar bears (Ursus maritimus) at Svalbard. J Toxicol Environ Health A 62(4):227-241

Southcott RV, Chesterfield NJ, Warneke RM (1974) The vitamin A content of the liver of the Australian fur seal, Arctocephalus pusillus doriferus. Aust Wildl Res 1:145-149

Tawara T, Fukazawa R (1950a) Studies on Kitol I. Preparation of kitol from whale liver oil. Sci Rep Whales Res Inst 3: 85-88

Tawara T, Fukazawa R (1950b) Studies on Kitol. II. Influence of kitol fraction on the determination of the international unit of vitamin A. Sci Rep Whales Res Inst 3:89-95

Thompson JN (1976) Fat-soluble vitamins. Comp Anim Nutr 1:99-135

Tornero V, Borrell A, Forcada J, Pubill E, Aguilar A (2004) Patterns of retinoid and lipid concentrations in the blubber of common dolphins (Delphinus delphis): implications for monitoring vitamin a status. Comp Biochem Physiol B 137: 391-400

Wagner KH (1939) Vitamin A und $\beta$-carotin des finn-, blauund spermwals. Joh A Barth Verlag, Leipzig

Wetlesen CU (1938) Whale liver. Nor Hvalfangst-Tidende 27: 262-264

Wolf G (1984) Multiple functions of vitamin A. Physiol Rev 64: 873-937

Submitted: March 8, 2004; Accepted: July 6, 2004

Proofs received from author(s): September 29, 2004 